\title{
GOVERNMENTAL PROFESSIONAL DEVELOPMENT INITIATIVES FOR THE IMPLEMENTATION OF LANGUAGE POLICIES AND CURRICULUM GUIDELINES: SECONDARY SCHOOL TEACHERS' EXPERIENCES, CHALLENGES AND VIEWS
}

INICIATIVAS GUBERNAMENTALES DE DESARROLLO PROFESIONAL PARA LA IMPLEMENTACIÓN
DE POLÍTICAS LINGÜÍSTICAS Y LINEAMIENTOS CURRICULARES: EXPERIENCIAS, DESAFÍOS
Y OPINIONES DE MAESTROS DE EDUCACIÓN BÁSICA SECUNDARIA
LES INITIATIVES GOUVERNEMENTALES DE DÉVELOPPEMENT PROFESSIONEL
POUR L'IMPLÉMENTATION DES POLITIQUES LINGUISTIQUES ET DES LIGNES DIRECTRICES
CURRICULAIRES: EXPÉRIENCES, DÉFIS ET AVIS DES ENSEIGNANTS DE L'ÉDUCATION SECONDAIRE

Ana María Sierra-Piedrahita M. A. in Secondary and Continuing Education, University of Illinois at Urbana-Champaign, USA, Ph. D. in Curriculum and Instruction, University of Wisconsin, Madison, USA. Associate professor and researcher, School of Languages, Universidad de Antioquia (Colombia), member of the research group on Culture, Identity and Language Education, Universidad de Antioquia.

Escuela de Idiomas, Universidad de Antioquia, Calle 70 N. ${ }^{\circ}$ 52-21, Medellín, Colombia.

https://orcid. org/0000-0002-3051-1958

ana.sierra@udea.edu.co

Paula Andrea Echeverri-Sucerquia M. S. and Ph. D. Education (Curriculum and instruction), Southern Illinois University, USA. Full-time teacher educator and researcher, School of Languages, Universidad de Antioquia (Colombia). Member of the research group on Culture, Identity and Language Education,

\begin{abstract}
A case study was conducted to explore public secondary school teachers' perspectives, practices, and experiences concerning the design and implementation of the English curriculum, as well as the professional development offered by the government in order to implement language policies and curriculum guidelines in the city of Medellin, Colombia. The study lasted one year and included a survey, the analysis of curriculum documents from five selected institutions, and focus group interviews as data collection instruments. Results indicate that the initiatives provided by the government have not been effective in supporting teachers in this endeavor as they have been very limited in terms of curriculum design, and reflect a technical view of teacher learning. In addition, several contextual and social factors have tremendously affected the implementation of language policies and curriculum guidelines in schools. Besides, teachers point to several needs, including that they have more time to appropriate and implement reforms, that they be included in policy-making as affected parties, that professional development initiatives be freed from political and economic interests and that they be offered a preparation that combines improving their language proficiency, English teaching methodologies and curriculum design.
\end{abstract}

Keywords: curriculum development; language policy; professional development; in-service teachers; public schools; English teaching.

\section{RESUMEN}

El presente estudio de caso se propuso explorar las perspectivas, prácticas y experiencias de maestros en instituciones públicas de educación básica secundaria sobre el diseño y la implementación del currículo de inglés, así como el desarrollo

Received: 2018-08-03 / Accepted: 2019-08-01 / Published: 2020-01-28

http://doi.org/10.17533/udea.ikala.v25n01a13 
Universidad de Antioquia.

https://orcid.

org/0000-0002-0660-1363

paula.echeverri@udea.edu.co
This article reports some of the findings of a study conducted by the authors to explore public secondary school teachers' perspectives, practices, and experiences concerning the design and implementation of the English language curriculum in the city of Medellin, funded by Universidad de Antioquia through the Committee for Research Development (Comité para el Desarrollo de la Investigación - $\mathrm{CODI}-$ ). profesional ofrecido por el gobierno para implementar políticas lingüísticas y directrices curriculares en la ciudad de Medellín, Colombia. El estudio se realizó a lo largo de un año, en el cual se aplicó una encuesta, se analizaron documentos curriculares de cinco instituciones seleccionadas, y entrevistas en grupos focales como instrumentos de recolección de datos. Los resultados indican que las iniciativas dadas por el gobierno no han sido efectivas para apoyar a los maestros en su labor, pues han sido muy limitadas en términos de diseño curricular, y reflejan una visión técnica de la formación docente. Además, varios factores sociales y contextuales han afectado la implementación de las políticas lingüísticas y de pautas curriculares en las instituciones. Por otro lado, los docentes señalan varias necesidades, como el tener más tiempo para apropiar e implementar las reformas, que se les incluya en la formulación de políticas como partes afectadas, que se liberen las iniciativas de desarrollo profesional de intereses políticos y económicos y que se les ofrezca una preparación que combine el mejoramiento de su competencia lingüística, las metodologías de enseñanza del inglés y el diseño curricular.

Palabras clave: desarrollo curricular; políticas de lengua; desarrollo profesional; profesores en servicio; colegios públicos; enseñanza de inglés.

\section{RÉSUMÉ}

Cette étude de cas a été menée afin d'explorer les perspectives, les pratiques et les expériences d'enseignants d'écoles secondaires publiques de Medellín suite à l'implémentation du curriculum d'anglais langue étrangère et au développement professionnel offert par le gouvernement comme faisant partie des politiques linguistiques et des directrices curriculaires. Cette étude s'est déroulée sur un an au cours de laquelle nous avons collecté les données suivantes: un questionnaire auprès des acteurs, l'analyse des documents curriculaires de cinq institutions scolaires et des entretiens de groupe. Les résultats montrent que les initiatives $\mathrm{du}$ gouvernement pour appuyer les enseignants n'ont guère été probantes. En effet, quant à la conception curriculaire, celles-ci sont très restreintes et traduisent une vision technique de la formation des enseignants. De plus, plusieurs facteurs sociaux et propres au contexte affectent énormément la mise en place des politiques linguistiques et des orientations curriculaires. Par ailleurs, les enseignants invoquent différents besoins: celui de disposer de plus de temps pour élaborer les réformes et les mettre en place; celui d'être inclus dans la prise de décision sur les politiques qui influencent leurs pratiques ; celui de séparer les initiatives de formation professionnelle des intérêts politiques et économiques, et celui d' une formation qui leur permette $d$ 'actualiser leur compétence linguistique en anglais, leurs méthodologies d'enseignement et la conception curriculaire.

Mots clés : développement curriculaire ; politiques linguistiques ; développement professionnel ; enseignants en exercice ; écoles publiques ; enseignement d'anglais. 


\section{Introduction}

Given the status of the English language around the world, Colombia, like many other countries, has adopted educational policies and programs to promote English learning as a way of facilitating its population's access to the global economy and further the country's economic development (Gómez-Sará, 2017). However, high-school students and teachers' English proficiency fall short of government expectations. According to English proficiency exams conducted by the national andlocal government, there is evidence of low proficiency levels among students and teachers. In response to this issue, throughout the last 14 years, the national government has launched four programs to promote the teaching and learning of English across the country. The last of those programs was named Bilingual Colombia 2014-2018, which, as with the previous ones, proposes a way of improving English teaching and learning processes in public institutions by having teachers and administrators go through a series of tasks.

To improve teachers and students' proficiency levels, several strategies have been implemented by the government. For instance, students from ninth to eleventh grade have been offered English courses, schools have been provided with material and technological resources to improve teaching, and there is a flexible and adaptable curriculum to guide the instruction of English. Additionally, teachers have been provided with immersion programs and professional development initiatives through partnerships with private and public universities and the local government. This last strategy is not sufficient if it is not linked to teachers' preparation to revise, design or adapt the curriculum according to the government's expectations, and language teaching and learning trends. Subject matter knowledge is not enough to teach it, and reaching the expected proficiency level also requires the knowledge and ability to develop curricula and syllabi that favor students' English language learning.

A review of the Colombian literature, conducted by the authors in well-known indexed journals in the field, shows that there is not enough information on how public secondary school teachers conceptualize, revise, adapt or design the curriculum for the English area. Most research conducted has focused on: a) reviewing and proposing a new curriculum in public schools (e.g. Cadavid, 2003; Clavijo, Guerrero, Torres, Ramírez, \& Torres, 2004; Ordóñez, 2011; Ortiz, Camelo, Martín, Sarmiento \& Ruiz, 2006); b) proposing the implementation of a methodological strategy as the central part of the curriculum (e.g. Gaona, Suárez \& González, 2001; Vargas \& Abouchaar, 2001); c) designing and implementing a curriculum unit in a course of a teaching program at a public university (Ariza, 2004); d) proposing curricular changes through collaborative inquiry among teachers in a public school (Aguirre Garzón, 2018); and e) proposing a professional development program in a university program to implement a new curriculum (Ferrer- Ariza \& Poole, 2018).

Consequently, this study seeks to explore the perspectives, experiences and challenges that public secondary school teachers have regarding curriculum development and implementation in Medellin. In this sense, it seeks to answer the following research question: What are the perspectives, experiences and challenges that English teachers in public schools in Medellin identify in relation to curriculum design and implementation in their institutions? This question implies looking at the professional development that teachers have been offered to be able to work on curriculum design and implementation in their schools, which is the focus of the present article. The results of the study concerning teachers' perspectives about the English curriculum as well as their practices, experiences and challenges when designing and implementing it are reported in another article.

In this paper, we will first present the theoretical background that guided the study. Then, we will describe the research method utilized and, finally, we will discuss the findings and draw some conclusions for policy implementation and professional development. 


\section{Theoretical framework}

In this section, we briefly define curriculum development and explain its connection with syllabus design in language teaching. Moreover, we briefly present the curriculum model that has influenced curriculum and syllabus design in language teaching and explain why these processes need to be supported by teachers' professional development for an adequate implementation of language policies and curriculum guidelines in the current educational reform.

Language curriculum development is an aspect of the broader field of curriculum development or curriculum studies that has to do with the processes of designing, revising, implementing and evaluating language programs. Curriculum development consists of determining learners' needs, analyzing the context, considering the impact of contextual factors, planning learning outcomes, organizing a course,selectingand preparingteachingmaterials,providing effective teaching, and evaluating the program (Richards, 2001). In language teaching, the history of curriculum development begins with the notion of syllabus design —one aspect of curriculum development that emerged as a major factor in language teaching due to changes in approaches/methods to language teaching (Richards, 2001). In this sense, different types of approaches to foreign language syllabus design are found in the literature, such as a structural syllabus, notional/functional syllabus, situational syllabus, skill-based syllabus, content-based syllabus, task-based syllabus, communicative syllabus, etc. (Rahimpour, 2010; Woods, Luke \& Weir, 2010). This reflects a change of paradigm towards a sociolinguistic model focusing on communicative language teaching (Woods, et al., 2010). However, a renewed interest in teaching English, given its status as a global language and changes in the purposes for which people studied English, influenced the growth of language curriculum development (Richards, 2001; Woods, et al., 2010).

Curriculum models, such as the outcome-based model, process-based model, and traditional content model, have offered different approaches to what should be taught and learned. Consequently, elements of major curriculum models are reflected in the curriculum development and syllabus design of school (Woods, et al., 2010). In the case of the construction of English curricula, Tyler's classical model from the end of the 1940s is dominant (Pennycook, 1990); in this model, a series of plans oriented towards the accomplishment of a specific objective is prescribed. For instance, the correct use of a linguistic structure (when language is seen as an end), or effective performance in a communicative situation (when language is seen as a means). It could be stated that those who share this way of conceptualizing the curriculum are not interested in understanding or explaining the meanings and the interactions that mediate educational processes and neither the practices that take place in institutions every day.

According to Richards (2001), since the 1980s, curriculum development processes such as needs analysis, context analysis, goal setting, syllabus design, material design, evaluation, and teacher preparation, are central in language program design. That is, curriculum development is no longer seen as the technical, rationalist and linear approach of Tyler's model. Focusing on the interrelated processes that make up curriculum development, to revise and (re)design language teaching curricula, requires putting teachers at the center of the planning and decision-making process in schools (Richards, 2001). However, the role of language teachers has so far largely been one of consumers or implementers of others' curricula and syllabi, instead of being the designers of their own (Bell, 1983 as cited in Rahimpour, 2010), as this study has found.

To change this situation -while considering that knowledge about language teaching and learning is tentative and incomplete, and that language teachers require opportunities to update their knowledge (Richards \& Farrell, 2005) and skills- teachers need to make use of their professional knowledge to make informed decisions about teaching and learning. That is, they should have or develop the 
professional capacity to interpret, adapt and adjust curriculum content, considering particular school's context and students' characteristics, background and progress. They should keep a balance between centralized standards, curriculum mandates and professional decision making (Woods, et al., 2010). Consequently, they should be equipped with the skills and knowledge to (re)design their own curricula and syllabi (Rahimpour, 2010), and in this way show professional expertise, mostly in the ongoing educational reform trend. Initiatives for professional development can provide teachers with the opportunity to update and expand such knowledge and skills.

\section{Educational reform and professional development}

The literature regarding professional development shows that there is a general agreement among researchers and scholars that professional development needs to be designed in a way that supports educational reform. Educational reformers have realized that teachers are the most important agents of change and their professional development should be a key component in any reform initiative to ensure its effectiveness (Villegas-Reimers, 2003). Therefore, the success of educational reform initiatives depends to a great extent on how qualified and effective teachers are (Day \& Sachs, 2004; Garet, Porter, Desimone, Birman \& Kwang, 2001) as well as how motivated, knowledgeable and skillful they are (Day \& Sachs, 2004).

However, in Colombia, and particularly in Medellin, as the results of this study indicate, most in-service language teachers in schools have not been offered professional development programs by the government to help them develop the knowledge and skills to (re)design and implement a curriculum that favors students' learning. When they have experienced a different type of professional development concerning curriculum development and implementation, this has been thanks to the efforts of some scholars in the language teaching field to provide them with such an opportunity (e.g. Aguirre Garzón, 2018; Cadavid, 2003; Clavijo et al., 2004;
Chaves \& Guapacha, 2016; Gaona, Suárez \& González, 2001; Giraldo, 2014; Ordóñez, 2011; Ortiz et al., 2006; Vargas and Abouchaar, 2001).

Therefore, what most in-service teachers have been offered throughout the years are traditional professional development initiatives, based on a technical view of teachers' learning and development (SierraPiedrahita, 2016) that do not contribute much to their learning (Fullan, 2001; McCotter, 2001; Randi \& Zeichner, 2004), and "rarely provide sufficient follow-up and support for meaningful and lasting improvement" (Lieberman \& Wood, 2001, p. 174). They have been trained to implement reforms for which they are normally told what to teach and how to teach it (Robertson, Samoff, Sleeter, Tatto, \& Torres, as cited in Zeichner, 2011), as is the case with the program Colombia Bilingüe 20142018. Within this reform - mostly through courses and workshops - teachers have been instructed regarding the content and methodologies specified by policymakers, how the reform works, and how it should be implemented in schools (Avalos, 2004; Sierra-Piedrahita, 2016), normally with an imposed curriculum. The challenge of implementing a new curriculum becomes greater for teachers because they have not been invited to participate in its design, and almost no time has been devoted to preparing them for its implementation (Avalos, 2004). Thus, language teachers in schools normally teach a scripted and prescribed curriculum, because the professional development they receive does not prepare them to (re)design their own school curriculum paying attention to the needs, interests and specific contexts of their students. In addition, they are not given the resources to embark on such task.

Clearly, teachers need to learn a significant amount in order to carry out the type of instruction that leads to the type of student learning that reformers contemplate (Ball \& Cohen, 1999). The litera-ture about professional development indicates that the view of professional development for teachers is changing from a technical model to a teacher learning model in which teachers are seen as intellectuals who can generate knowledge through constant 
examination of their practice. For the national and local government and many schools, the adoption of new forms of professional development is not considered and, as discussed above, teachers still experience traditional forms of professional development. Besides, they are not invited to play the active role they could be playing in their own professional development (Richards \& Farrell, 2005). Therefore, professional development, as conceived and designed by the government today, has a remote possibility of significantly impacting teachers' knowledge and skills, and students' performance (Elmore, 2002).

Language teachers in schools should be able to make informed decisions about curricula, and the professional development programs they are offered must contribute to their preparation and direction in this sense. Preparing them tobe able to maintain abalance between the interests of reformers, their own needs and interests as professionals (Day \& Sachs, 2004 as cited in Sierra-Piedrahita, 2016; Martin, Kragler, Quatroche, \& Bauserman , 2014), students' interests and needs (Martin et al., 2014), and their contexts and realities, is paramount. The findings of this study point to these fundamental issues.

\section{Research method}

We used a qualitative case study to understand English language curriculum design and implementation in secondary schools, and the professional development teachers received for such an endeavor. A case study is a research process that entails the study of an issue that a researcher explores through a case within a bounded system, meaning a context or a setting (Merriam, 1998; Stake, 2005, 2006). Our research focused on the case of English language curriculum design and implementation in secondary schools. We wanted to understand the perspectives, experiences and practices of secondary school teachers when designing and implementing the English curriculum in their schools and the preparation they received to carry out this task, by interpreting the meaning of the issue for the teachers involved (Merriam, 1998), understanding its complexities (Stake, 2005), and considering the specific contextual conditions and activities that needed to be understood.

\section{Data collection}

Data were collected through a survey, document analysis, and focus group interviews. The survey was applied to 75 secondary school English teachers out of a pool of 610 teachers who were hired in government schools. The survey, applied through SurveyMonkey, gave us quantitative information to characterize the population and their beliefs about curricula and curriculum design practices and experiences (see appendix with the questions that were included in the survey). The document analysis was conducted in five selected urban schools. The criteria used to select these schools were: those with a greater number of teachers who participated in the survey, diversity in their geographic location, and access -i.e. schools that have been part of previous research projects with colleagues from our Language Teacher Education Program, or that were practicum sites for our pre-service teachers in our Teacher Education Program. We analyzed their institutional documents such as their Proyecto Educativo Institucional, - PEIarea plans and curricular guidelines to identify the theoretical and methodological elements that teachers consider when designing the English curriculum, and to identify the prevailing curricular structures in public schools. Finally, five focus group interviews were conducted with teachers from the selected institutions who willingly accepted to participate after signing a consent form. The number of teachers from each institution oscillated between three and eight, for a total of 21 teachers. Interviews were conducted not only to expand on the information obtained through the survey and the document analysis, but also to understand their beliefs, experiences and practices concerning curricula and curriculum design, their professional development experiences and needs, the preparation they were offered to respond to policies and curriculum guidelines, and the factors 
that affected the implementation of those policies and curriculum guidelines in their schools.

\section{Data analysis}

Data from the survey was analyzed using SurveyMonkey. Data from the schools' curriculum documents and the focus group interviews were systematized and analyzed following an inductive and deductive approach and according to the recommendations of various authors such as Burnaford et al. (2001) and Anderson et al. (1994), by which data is categorized and organized by relevant themes according to this study's research question. We read the data several times to identify themes across the different sources of data, which helped us to establish preliminary and final categories. We wrote analytical notes based on what we found in the data and compared and contrasted categories to establish a relationship among them and to build interpretations. To guarantee validity and trustworthiness in interpretations, we triangulated the different sources of data. To be able to manage the amount of information we collected, we used NVivo, a software package used for qualitative data analysis.

\section{Results}

In this section, as stated above, we report only the results of the study concerning the professional development teachers have been offered by the government to implement language policies and curriculum guidelines. Three themes emerged from the data analysis: professional development initiatives offered to teachers for curriculum design and their characteristics, factors that affect the implementation of language policies and curriculum guidelines, and teachers' views about policies and the government's professional development initiatives. It is important to clarify at this point that the evidence presented in this section comes from the focus group interviews, because it was through the teachers voices that we could clearly expand on and understand the information obtained through the other data sources concerning their experiences and challenges in terms of professional development for curriculum design and implementation.

\section{Professional development offered to teachers for curriculum design and its characteristics}

The preparation teachers have received has been provided by a myriad of public and private institutions such as Casa del Maestro, Caja de Compensación Familiar Comfenalco, universities, publishing houses, José Félix de Restrepo high school (INEM), and the Secretary of Education's Office. These initiatives have focused on improving language proficiency, using Information and Communication Technologies (ICT's) and preparing immersion experiences, but have been very limited in terms of curriculum design. Teachers complain about these initiatives because, in many occasions, they have been promised a course or workshop on language teaching methodologies, but these end up being pure grammar courses or language preparation courses with an emphasis on a particular textbook, or just courses and workshops to complete hours for a publishing house to promote their publications. Due to the focus of these initiatives, many teachers have come to believe, for instance, that the workshops they have attended in the past and that are sponsored by publishing houses and taught by native speakers to promote and sell their textbooks, are better than the workshops offered by these public or private institutions, because at least they are ludic and do not focus on grammar topics.

Teachers believe that what they have learned in these professional development initiatives - which normally translate into workshops and coursesis not significant because these are short-term and not continuous. Courses, for instance, had been offered every four years. Moreover, when they have been invited to participate in long-term initiatives, such as Expedición Currículo - an initiative being implemented in the institutions at the time we conducted the study - they felt that, as with short-term initiatives, these were intended to complete a large number of hours and assignments, but not to learn about teaching methodologies and teaching strategies. The following quote illustrates this issue: 
I told the girl who was in charge of Expedición Currículo: "No, I don't want to [attend], do not count on me, I don't want to go there to complete a bunch of hours and assignments and a bunch of things, no." You go there thinking that you are going to improve your methodology and [teaching] strategies and all that, but you end up completing a bunch of hours for a publishing house. (I. E.2)

In addition, programs are limited to ambitious courses with many requirements in terms of admission, weekly attendance, and assignments. Concerning admission requirements, for instance, teachers were offered a trip to Washington as an incentive to participate in courses and improve their language proficiency level, but to access this possibility one of the requirements was not to be close to the age of retirement. Therefore, teachers felt rejected or discriminated against, given that they would be still teaching for many years before they actually would retire. Another admission requirement was to have a minimum of five years of teaching experience, which left many of them unable to access training

144 programs. In terms of assignments, the programs were neither flexible, nor offered under conditions teachers considered adequate to be able to participate, such as appropriate schedules and types of assignments. For instance, they had to submit a large number of grammar exercises from textbooks and online platform exercises. Here is what one of the teachers expressed about course schedules and assignments:

I went twice and time was definitely not sufficient in the first week because there was a lot of work and I also had a lot of work at home. So when I saw the amount of homework they assigned that first week, with the [online] platform, and that I had to be there from 8 am to $2 \mathrm{pm}$, I thought, this is impossible. I quit because of that. (I.E.3)

With so many grammar assignments, graduation requirements and hours they had to invest in courses, teachers felt they were not learning things for immediate application in their classrooms, which discouraged them from attending.

Look, the course I attended was offered by [one university], and there was a bunch of homework. And to graduate you have to submit a project. So, I said to myself: "Do
I come here to learn new/different things to implement them in the classroom or do I come to study grammar again?" So I'd rather stay home. (I.E.1)

Other issues that characterized courses and discouraged teachers from attending were that many of them were consistently taught in Spanish and many instructors, according to the teachers, did not have an adequate language proficiency level, to the point that sometimes teachers felt they needed to correct their instructors' language mistakes. This issue discouraged teachers from attending courses because they felt they did not have good English language models to follow or to learn from.

\section{Factors affecting the implementation of language policies and curriculum guidelines}

Several factors affected the implementation of curriculum guidelines in public secondary schools, some are related to the school context and others to the social context. In terms of the school context, most primary school teachers are not qualified to teach English; therefore, secondary school teachers do what they can with their students' limited knowledge of the language once they move to secondary grades. As a result, students do not have the English language proficiency level they are expected to acquire. Moreover, in primary schools, students are only taught one hour of English per week, an insufficient amount of time that tremendously affects what they are able to learn. In addition, in many schools English is not even taught in primary grades, when this is clearly the basis for their learning process. To aggravate the situation there is the constant missing of classes due to different extracurricular activities, affecting students' continuity in learning the language. Moreover, teachers do not have sufficient resources to teach English. The following quote illustrates the current situation in schools with the implementation of the English standards set by the national government and the local curricular initiative Expedición Currículo:

Right now [the policy] is not applicable here, because of the lack of English teachers in elementary schools and the limited amount of hours of English 
instruction per week [...] Also, right now in secondary schools, it is impossible to implement that curriculum plan [Expedición Currículo] because the content they want us to teach in $6^{\text {th }}$ grade we are hardly teaching them in $8^{\text {th }}$ grade $[. .$.$] . Yesterday, we were revising the$ Expedición Currículo document and we concluded that it requires us to teach the simple past in $6^{\text {th }}$ grade when in reality we are teaching that in $8^{\text {th }}$ grade [...] And here we are not taking into account that half of the class has difficulties in understanding simpler topics. So, right now it is impossible to apply that curriculum plan [...]. [Moreover] the Ministry of Education does not assign English teachers for primary schools. English hours in schools are not enough, resources are not enough, [and] the training for teachers is not enough. (I.E.4)

Teachers are specific about the kinds of resources they need and point to the lack of technological resources to support the teaching of English.

We need to increase the possibility of using ICT in the institution and [the government] should make sure that institutions are well equipped with a good English lab or at least that teachers have access to an audiovisual lab and that the children also have access to computers and all that. (I.E.5)

Students' lack of motivation and apathy towards learning English is also evident, which affects their commitment to learn. Too often, teachers do not know what to do in terms of methodology to change this reality. Besides, the number of students per group is also an issue to consider, as expressed by one of the teachers:

Teachers should be better prepared [to use different methodologies and teaching strategies] [...]. We need more hours of English per week. Teaching a language class to a group of 25 students is not the same as teaching a group of 50 . That's a difficulty. (I.E.5)

Furthermore, the examination system in schools makes it difficult for students to accomplish the level they are expected to achieve, because they can be promoted to the next grade even if they fail several subjects. Teachers get almost no support from parents to help students improve their school performance, given the fact that most of the time parents are at work, and a great number of students do not have parents and live with other relatives. Some parents also ask teachers not to be too demanding with their children. One teacher commented on some of these contextual factors and their influence on what they are expected to do with their students:

With the current education system in Colombia it is not possible to achieve the expected proficiency level for students because [...] in 6th grade we have to teach all elementary grades intensively, then in 7 th grade you keep reviewing topics because of the amount of hours of English in schools, three hours per week, and because there is no opportunity for practicing English [...], plus the evaluation system does not help [as students can fail many subjects and still pass the grade]. (I.E.2)

Therefore, the reality is that many contextual factors affect the implementation of policies in schools, but at the same time, and most of the time, many social factors affect this implementation as well. On a daily basis, teachers must focus on what they call the social part of education so that students do not end up involved in drugs, gangs, prostitution, etc. They do not perceive their work as free of the influence of student's social reality and this has big repercussions on what they are able to achieve with their students. Apart from teaching them the language, they feel that they need to rescue their students from bad social influences outside of school, a job that many of them have to do without parents' support. As one teacher explains: "education has changed and has become a social work to rescue students from so many things outside [of school] that are more interesting for them [such as drugs, gangs, etc.]." (I.E.2).

In addition, they have to face and deal with other issues such as students' affective and learning problems, poverty, hunger, domestic violence, early pregnancies, etc. In this respect, one teacher commented on the social problems they have to deal with while at the same time trying to teach English, making their work more difficult:

Then there is the social part which is a huge problem. And achieving the English level [we are expected to achieve] seems like unreal. So, one does both things at the same time, intervenes the social part and tries to teach the English competencies, but achieving something with English is very difficult because the [social] problems are huge. (I.E.4). 
Clearly, school-related and social contexts have had an enormous impact on the work of teachers as they try to implement language policies and curriculum guidelines. However, this implementation has also been hindered by the way the policies were conceived, and the way teachers have been prepared to accomplish such task, as will be explained in the next section.

\section{Teachers' views about language policies and the government's professional development initiatives}

The implementation of policies is linked to professional development initiatives as it is assumed that if teachers participate in such initiatives, they will be able to implement policies quickly and effectively. Nonetheless, this has not been the case in schools in the city. The way in which the policies were conceived has hindered their implementation, despite the government's efforts to prepare teachers for this task. Below we list the reasons provided by the teachers to explain this situation.

First, teachers question the lack of communication between the national and local government and teachers. They manifested that the Ministry of Education or the local government only come to them to inform them about the English standards or curricular initiatives they want to implement, but there is a lack of continuity in their visits and dialogue between them is nonexistent. They are not asked about the policies that they are required to implement, so these policies end up being completely decontextualized and designed for other realities and contexts, rather than public schools. Teachers consider that although the people involved in governmental initiatives are talented, they do not know the schools' realities and the social and contextual issues that affect them, all of which have an effect on what can be achieved with the students. The same occurs with the professional development initiatives teachers are offered. They are invited to participate to be able to implement the policies or curriculum guidelines created by policymakers, however, the initiatives are not significant for them because they are decontextualized and do not consider their needs and interests, for instance, in terms of curriculum development.

Second, the national or local government does not give teachers sufficient time to appropriate and implement one initiative or reform and observe its results, and in the middle of its implementation they are asked to implement a new change. Teachers believe this happens because policymakers easily assume that a plan does not work, or because they realize that achieving a high language proficiency level is an impossible goal. Proof of this is that the country's deadline to become bilingual has been extended. One teacher expressed the following about the implementation of policies:

[...] if from the Secretary of Education they are proposing a new change, it is because they see that this is not working. They see that they are not accomplishing what they wanted. [...] I think that we have invested two years in the recontextualization project, which consisted in reorganizing the curriculum according to the school context and taking into account the standards set by the Ministry of Education and what the students have to achieve at the end of their learning process. What is proposed is good, but now we have Expedición Currículo and we have invested very little time in the recontextualization project, $[. .$.$] We have$ invested two or three years in this project and now they [the government] is modifying things because it supposedly didn't work, but we are not given enough time, we are asked to change things while we are implementing them so we are not giving adequate time to projects and processes. (I.E.4)

In general, teachers believe that the plan to make the country and the city bilingual has been a failure, and that such a goal was unrealistic or almost impossible to achieve considering the actual factors and resources in public schools.

Third, there are always political and economic interests at play in the professional development initiatives teachers are offered. According to teachers, these initiatives have been numerous though not always adequate because they are intended only to account for money invested by politicians in their campaigns or by any political party during their term 
in office. Therefore, initiatives are created just to display numbers and account for the millions that have been invested to achieve the expected language proficiency levels in teachers and students. Nonetheless, those strategies failed to meet the goal of improving language proficiency among the targeted population. Furthermore, some teachers questioned the fact that in order to account for the huge amount of money invested in courses and workshops, too often elementary and secondary school teachers -including those who did not participate in the initiatives - were called to accept class materials as presents. In addition, those in charge of the initiatives almost begged teachers to participate in courses because, as stated above, teachers did not feel motivated to do so because these are not planned to respond to their needs and interests, and are ambitious in terms of their requirements and assignments, as one teacher stated:

I mean the courses can be good [...] but the financial part is also there with the Nutresa Group, [for example], and when the National Bilingual program was launched that was super big. EAFIT University was in charge of the program, the Nutresa Group invested money. The government was also there represented by the city mayor. So, there is a lot of money invested there so money needed to be justified in courses. They called us and gave us presents. They almost begged us to be in those [courses] so that the money could be justified. But those courses were very ambitious, [...] extremely long and we had to respond to some virtual hours, in fact, it was like doing a master's program. (I.E.3)

Another teacher, for instance, associates the short duration of courses they have been offered to these being a mere requirement to be fulfilled in order to account for the money granted by the government.

[...] We need initiatives that are continuous because those offered by the Ministry of Education last only two or three months and that is it. And what is curious about this is that what they are looking for is to spend the money [that was invested] so [this is why] nothing is accomplished. (I.E.1)

All these issues have led teachers to consider the type of professional development they require to be able to implement the policies and curriculum guidelines in their schools and help their students achieve the expected language proficiency level. They need preparation that focuses on improving their language skills and English teaching methodologies, as well as curriculum design or a combination of these. Some teachers argued that even though they can have a good language proficiency level, they lack, for instance, the knowledge about language teaching approaches that are appropriate for their students' needs, context, and diversity. Being updated is essential for them because many years have passed since they finished their undergraduate programs. Concerning this preparation one teacher describes what they would need or like to find in instructors and professional development initiatives:

If we have the professional that knows about curricu-
lum [design], we don't have the professional who talks
about it in English. We need both things. We always
have someone who asks us to speak English, and I love
to participate in all that because we practice and re-
member something, but we need people who know
[about curriculum design], people who are able to
teach a course [about curriculum design] in English.
That would be great! That is what we need [...], to in-
tegrate both things. (I.E.4)

Finally, teachers expressed their desire to have universities with language teacher preparation programs working more closely with public schools to help them articulate teaching and language because these are not included at all in the initiatives offered to them and because they require a strong instruction that is led by specialists who really know about curriculum design.

\section{Discussion and conclusions}

In light of new language policies, curriculum guidelines and English teachers' pedagogical practices in public schools, limiting the focus of professional development initiatives to improving teachers' language proficiency level does not seem to contribute to accomplishing the goal of improving English teaching in schools. This study demonstrates the support teachers need to learn about curriculum development and design and language teaching approaches to accomplish not only the expected 
language proficiency level but also the job of educating students to succeed in school and in life.

This study also provides insights into the influence of contextual factors in the implementation of policies and curriculum guidelines in public schools. Most of the contextual factors that depend directly on the government, such as the lack of English teachers in elementary schools, insufficient resources to teach English, the examination system, the insufficient or complete absence of hours of English in elementary schools, to name but a few, require immediate action on the part of the national and local government so that the goal of achieving high levels of English language proficiency can become a reality. Since the creation of the National Plan of Bilingualism in 2004, several studies and articles written by different academics in the country have repeatedly demonstrated the effects of contextual factors on the implementation of this policy, although authors refer to these in different ways (e.g. Correa \& González, 2016; Gómez-Sará, 2017; Correa et al., 2014; Correa \& Usma, 2013; Usma, 2015). Despite the results of these studies and analyses, the government continues to ignore these issues and to believe that the solution to increasing English language proficiency in students and teachers is to provide teachers with English courses or workshops to train them on how a specific methodology works (Avalos, 2004; Sierra-Piedrahita, 2016) or how to use specific materials. Nevertheless, preparing teachers in curriculum design and addressing the factors that interfere with the implementation of policies and curriculum guidelines in public schools are still ignored. In addition, school administrators and teachers neither understand the negative effects of not modifying language teaching approaches in order to reduce students' lack of motivation and apathy towards learning English, nor do they understand the need to reduce extracurricular activities that interfere with classes in schools.

Moreover, the work teachers have to focus on daily in order to minimize the effects of social issues in schools does not favor the implementation of policies and curricular guidelines. Even though teachers have the desire to work on improving language proficiency among their students, they are still not able to connect social issues to the curriculum and implement other approaches for the teaching of English that would be beneficial for the students, as they could relate their learning with their real lives and realities. Designing a critical curriculum that is supported by critical language teaching approaches could contribute to this task. However, as stated above, this is not the only solution to support teachers in this endeavor. The impact of contextual factors in the implementation of policies and curriculum guidelines also requires immediate attention by the government and administrators in schools (Correa \& González, 2016, Correa et al., 2014; Sierra-Piedrahita, 2018).

Furthermore, teachers require enough time to appropriate and implement policies and curricular guidelines. As this study demonstrates, teachers feel frustrated as they have not been able to see the results of the implementation of any curriculum initiative because the government is constantly introducing new programs or curricular changes in the middle of the initiatives' implementation. They perceive this not only as improvisation but also as a way of interrupting processes that could be of benefit to their students. In addition, new programs or curricular changes should be introduced only when these are supported by systematic studies that indicate the need for such a change. Such modifications should not be driven by the agenda of any political party or new government, which normally set unrealistic deadlines to accomplish educational goals.

The appropriation and implementation of policies and curricular guidelines also require constant communication, dialogue and work with teachers. This study indicates that the lack of communication and dialogue between the national and local government and teachers makes teachers feel frustrated, disrespected and hopeless, as they are merely informed about initiatives and expected to implement them. Again, several authors have pointed out the importance of taking into account teachers' views and participation in the formulation of 
policies (Ávalos, 2004; Gómez Sará, 2017; Guerrero, 2010; Peláez \& Usma, 2017; Shohamy, 2009) and curriculum guidelines. They could contribute significantly given their experience and knowledge of the school context and students' social realities. Teachers want to be considered during the formulation of policies, and want to see themselves as curriculum designers rather than mere implementers.

For language policies and curricular guidelines to be implemented more effectively, teachers require professional development programs that really respond to their interests and needs (Day \& Sachs, 2004; Chaves \& Guapacha, 2016; Sierra-Piedrahita, 2016), and that support them inside their classrooms so that there is meaningful and continuing improvement of practice (Lieberman \& Wood, 2001). It is necessary to offer teachers programs that prepare them to design the English curriculum in their schools and that challenge them to introduce new/other language teaching approaches. However, such preparation cannot consist only of courses, workshops and lectures that are based on a technical view of teachers' learning and development (Sierra-Piedrahita, 2016). These have so far not contributed much to teachers' learning (Fullan, 2001; McCotter, 2001; Randi \& Zeichner, 2004), and have not been that effective in supporting teachers in the implementation of national and local policies or curriculum guidelines because of their characteristics, as this study shows it. As Elmore (2002) observes, professional development as it is designed today, in Colombia, has a remote possibility to significantly impact teachers' knowledge and skills, and students' performance.

Therefore, and as several studies in Colombia have demonstrated, in-service language teachers should experience a different type of professional development (see Cadavid, Quinchía \& Díaz, 2009; Cárdenas, 2004; Chaves \& Guapacha, 2016; Giraldo, 2014; Usma \& Frodden, 2003). They can be offered programs that include a combination of different professional development strategies that complement each other to really support teachers in their daily practices and specific contexts (LoucksHorsley et al., 2003; Sierra-Piedrahita, 2018).
Furthermore, these should be long-term and continuous (Day \& Sachs, 2004, Martin et al., 2014; Long, 2014; Richards \& Farrell, 2005) and should not end when the incumbent administration ends its term in office. In addition, these should not discriminate against certain teachers in their admission requirements. Assignments should also be significant for teachers; that is, related to their daily practice and with immediate applicability. Finally, programs' agendas cannot be guided by the economic interests of political parties, or by their desire to justify the amount of money invested in such programs. As demonstrated by this study, programs whose interests are guided by political and economic interests - and not by a real desire to support teachers in the implementation of curriculum guidelines and to respond to their interests and needs - end up interfering with attempts to implement curricular initiatives, as well as discouraging teachers from participating in professional development initiatives that would help them assume new challenges in their classrooms.

Curriculum development is an activity that normally poses big challenges to teachers. Many of them lack knowledge of the different components of the curriculum and how these should be articulated to create a pertinent curriculum that responds to students' needs and to a particular context. Moreover, teachers very frequently work on the design of the curriculum only because the national or local government or administrators demand that they do so, and not because they are convinced of the importance of designing a pertinent curriculum that can guide their students' work. If, as Richards (2001) observes, the success of the teaching and learning process depends on various processes of planning and implementation when developing a curriculum, then it is the job of policymakers and teacher educators to support teachers in this journey, as teacher themselves expressed in this study. Taking into account teachers' perspectives, practices and challenges, we can propose alliances between universities and public institutions with the purpose of improving not only teachers' learning processes but also students' learning processes inside public institutions and, as 
a result, offer students a better education to succeed in life. To carry out this fundamental task and execute the type of instruction that leads to the type of student learning that reformers contemplate (Ball \& Cohen, 1999), language teachers need to learn a great deal about the processes involved in curriculum development. Hopefully this study can contribute to begin this journey.

\section{References}

Aguirre Garzón, E. A. (2018). Unlicensed EFL teachers coconstructing knowledge and transforming curriculum through collaborative-reflective inquiry. PROFILE, Issues in Teachers' Professional Development, 20(1),7387. https://doi.org/10.15446/profile.v20n1.62323.

Anderson, G. L., Herr, K., \& Nihlen, S. A. (1994). Studying your own school: An educator's guide for qualitative practitioner research. Thousand Oaks, CA: Corwin Press.

Ariza, A., (2004). Curricular units: Powerful tools to connect the syllabus with students' needs and interests. PROFILE, Issues in Teachers' Professional Development, 5(1), 140-156.

Avalos, B. (2004). CPD policies and practices in the Latin American region. In C. Day \& J. Sachs (Eds.), International handbook on the continuing professional development of teachers (pp. 119-145). Glasgow, UK: Open University Press.

Ball, D. L., \& Cohen, D. K. (1999). Developing practice, developing practitioners: Towards a practice-based theory of professional education. In L. Darling-Hammond \& G. Sykes (Eds.), Teaching as the learning profession: Handbook ofpolicy and practice. San Francisco, CA: Jossey-Bass.

Burnaford, G., Fischer, J., \& Hobson, D. (2001). Teachers doing research: The power of action through inquiry. Mahwah, NJ: Lawrence Erlbaum Associates.

Cadavid, C. (2003). Teaching English in primary school through a spiral thematic curriculum. Íkala, Revista de Lenguaje y Cultura, 8(14), 81-97.

Cadavid, C., Quinchía, D., \& Díaz, C. (2009). Una propuesta holística de desarrollo profesional para maestros de inglés de la básica primaria. Íkala, Revista de Lenguaje y Cultura, 14(21), 135-158.

Cárdenas Beltrán, M. L. (2004). Las investigaciones de los docentes de inglés en un programa de formación permanente. Íkala, Revista de Lenguaje y Cultura, 9(1), 105-135.

Chaves, O., \& Guapacha, M. E. (2016). An eclectic professional development proposal for English language teachers.
PROFILE, Issues in Teachers' Professional Development, 18(1), 71-96. https://doi.org/10.15446/profile. v18n 1.49946

Correa, D., \& González, A. (2016). English in public primary schools in Colombia: Achievements and challenges brought about by national language education policies. Education Policy Analysis Archives, 24(83). https://doi.org/10.14507/epaa.24.2459.

Correa, D., Usma, J., \& Montoya, J. C. (2014). El Programa Nacional de Bilingüismo: un estudio exploratorio en el departamento de Antioquia, Colombia [National Bilingual Program: An exploratory study in the Department of Antioquia, Colombia]. Íkala, Revista de Lenguaje y Cultura, 19(1), 101-116.

Correa, D., \& Usma, J. (2013). From a bureaucratic to a critical-sociocultural model of policymaking in Colombia. HOW, 20(1), 226-242.

Clavijo Olarte, A., Guerrero Melo, C. H., Torres Jaramillo, C., Ramírez Galindo, L. M., \& Torres Mesa, N. E. (2004). Teachers acting critically upon the curriculum. Íkala, Revista de Lenguaje y Cultura, 9(15), 11-41.

Day, C. \& Sachs, J. (2004). Professionalism, performativity and empowerment: Discourses in the politics, policies and purposes of continuing professional development. In C. Day \& J. Sachs (Eds.), International handbook on the continuing professional development of teachers (pp. 1-32). Glasgow: Open University Press.

Elmore, R.F. (2002). Bridging the gap between standards and achievement: The imperative for professional development in education. Washington, DC: Albert Shanker Institute.

Ferrer Ariza, E., \& Poole, P. M. (2018). Creating a teacher development program linked to curriculum renewal. PROFILE: Issues in Teachers' Professional Development, 20(2), 249-266. https://doi.org/10.15446/ profile.v20n2.67937

Fullan, M. (2001). The new meaning of educational change ( $3^{\text {rd }}$ Ed.). New York, NY: Teachers College Press.

Gaona, E., Suárez, L., \& González, H. (2001). Becoming an efficient reader: A proposal for a school curriculum. PROFILE, Issues in Teachers' Professional Development, 2(1), 37-41.

Garet, M.S., Porter, A. C., Desimone, L., Birman, B. F., \& Kwang, S. Y. (2001). What makes professional development effective? Results from a national sample of teachers. American Educational Research Journal, 38(4), 915945. https://doi.org/10.3102/00028312038004915

Giraldo, F. (2014). The impact of a professional development program on English language teachers' classroom 
performance. PROFILE Issues in Teachers' Professional Development, 16(1), 63-76. https://doi.org/10.15446/ profile.v16n1.38150

Gómez Sará, M. M. (2017). Review and analysis of the Colombian foreign language bilingualism policies and plans. HOW, 24(1), 139-156. http://dx.doi.org/10.19183/ how.24.1.343

Guerrero, C. H. (2010). The portrayal of EFL teachers in official discourse: The perpetuation of disdain. PROFILE: Issues in Teachers' Professional Development, 12(2), 34-49.

Lieberman, A., \& Wood, D. (2001). When teachers write: Of networks and learning. In A. Lieberman \& L. Miller (Eds.), Teachers caught in the action: Professional development that matters (pp. 174-187). New York, NY: Teachers College Press.

Long, R. (2014). Federal investments in professional development: What do 50 years of experience tell us about what it takes to make a difference? In L. Martin, S. Kragler, D. Quatroche, \& K. Bauserman (Eds.), Handbook of professional development in education: Successful models and practices, PreK-12 (pp. 22-41). New York, NY: The Guilford Press.

Loucks-Horsley, S., Love, N., Stiles, K. E., Mundry, S., \& Hewson, P. (2003). Designing professional development for teachers of science and mathematics. $\left(2^{\text {nd }} \mathrm{Ed}\right.$.). Thousand Oaks, CA: Corwin Press.

Martin, L., Kragler, S., Quatroche, D., \& Bauserman, K. (2014). Handbook of professional development in education: Successful models and practices, PreK-12. New York, NY: The Guilford Press.

Merriam, S. B. (1998). Qualitative research and case study applications in education. Revised and expanded from "Case study research in education". San Francisco, CA: Jossey-Bass.

McCotter,S.S.(2001). Collaborativegroupsas professionaldevelopment. Teacher and Teacher Education, 17(6), 685-704. https://doi.org/10.1016/S0742-051X(01)00024-5

Ordóñez, C. L. (2011). Education for bilingualism: Connecting Spanish and English from the curriculum, into the classroom, and beyond. PROFILE, Issues in Teachers' Professional Development, 13(2), 147-161. https://doi.org/10.1016/S0742-051X(01)00024-5

Ortiz, A., Camelo, M., Martín, M. N., Sarmiento, M., \& Ruiz, M. (2006). Revising a foreign language curriculum: A challenging and enhancing experience at a public school in Bogotá. PROFILE, Issues in Teachers' Professional Development, 7(1), 9-29.

Peláez, O., \& Usma, J. (2017). The crucial role of educational stakeholders in the appropriation of foreign language education policies: A case study. PROFILE, Issues in Teachers' Professional Development, 19(2), 121-134. https://doi.org/10.15446/profile.v19n2.57215

Pennycook, A. (1990). Critical pedagogy and second language education. System, 18(3), 303-314. https:// doi.org/10.1016/0346-251X(90)90003-N

Rahimpour, M. (2010). Current trends on syllabus design in foreign language instruction. Procedia Social and Behavioral Sciences, 2, 1660-1664. https://doi. org/10.1016/j.sbspro.2010.03.254

Randi, J., \& Zeichner, K. M. (2004). New visions of teacher professional development. In M. Smylie \& D. Miretzky (Eds.), Developing the teacher workforce (pp. 180-221). Chicago, IL: Chicago University and Chicago Press.

Richards, J. C. (2001). Curriculum development in language teaching. Cambridge: Cambridge University Press.

Richards, J. C., \& Farrell, T. S. (2005). Professional development for language teachers: Strategies for teacher learning. Cambridge: Cambridge University Press.

Shohamy, E. (2009). Language teachers as partners in crafting educational language policies? Íkala, Revista de Lenguaje y Cultura, 14(22), 45-67.

Sierra-Piedrahita, A. M. (2016). Contributions of a social justice language teacher education perspective to professional development programs in Colombia. PROFILE, Issues in Teachers' Professional Development, 18(1), 203-217. https://doi.org/10.15446/profile. v18n1.47807

Sierra-Piedrahita, A. M. (2018). Changing teaching practices: The impact of a professional development program on an English language teacher. Íkala, Revista de Lenguaje y Cultura, 23(1), 101-120. https:// doi.org/10.17533/udea.ikala.v23n01a08

Stake, R. E. (2005). Qualitative case studies. In N. Denzin \& Y. Lincoln (Eds.), Handbook of qualitative research ( $3^{\text {rd }}$ Ed.), (pp. 443-466). Thousand Oaks, CA: Sage.

Stake, R. E. (2006). Multiple case study analysis. New York, NY: The Guildford Press.

Usma, J., \& Frodden, C. (2003). Promoting teacher autonomy through educational innovation. Íkala, Revista de Lenguage y Cultura, 8(14), 101-132.

Usma, J. (2015). From transnational language policy transfer to local appropriation: the case of the national bilingual program in Medellin, Colombia. Blue Mounds, WI: Deep University.

Vargas, N., \& Abouchaar, A. (2001). Project work as the central part of the curriculum. Profile: Issues in Teachers' Professional Development, 2(1), 83-86. 
Villegas-Reimers, E. (2003). Teacher professional development: An international review of the literature. International Institute for Educational Planning.

Woods, A., Luke, A., \& Weir, K. (2010). Curriculum and syllabus design. Kelvin Grove, QLD: Elsevier. https://doi. org/10.1016/B978-0-08-044894-7.00058-0
Yin, R. (2003). Case study research: Design and methods. Thousand Oaks, CA: Sage.

Zeichner, K. M. (2011). Teacher education for social justice. In M. R. Hawkins (Ed.), Social justice language teacher education (pp. 7-22). Bristol, UK: Multilingual Matters.

How to reference this article: Sierra-Piedrahita, Ana María, and Echeverri-Sucerquia, Paula Andrea (2020). Governmental professional development initiatives for the implementation of language policies and curriculum guidelines: Secondary school teachers' experiences, challenges and views. Íkala, Revista de Lenguaje y Cultura, 25(1), 137-152, http://www.doi.org/10.17533/udea.ikala.v25n01a13 